\title{
The Importance of Being 'On the Road': A Reading of the Journey in The Darjeeling Limited (2007) by Wes Anderson
}

\begin{abstract}
Road stories are significant cultural objects that "provide a ready space for [the] exploration" (Cohan and Hark 1997, 2) of different landscapes, contributing to the encounter of the traveller with him/ herself or with the Other. These cultural encounters offer the opportunity both for inner reflection upon the nation in which the protagonists travel. Such is the case of the Whitman brothers in The Darjeeling Limited (2007, Wes Anderson), who embark on a journey in India seeking spiritual enlightenment from the problems of the past. The confrontation with the foreign Other will not only put into perspective a changed notion of the Indian nation but also their true purpose in life. Based upon the idea of the transformative power of journeys, and considering The Darjeeling Limited as a road movie, this article analyzes the brothers' awakening as they travel deeper into the Indian landscape to emerge with a renewed sense of self.
\end{abstract}

Keywords: journey; road stories; cinema; transformation; The Darjeeling Limited; Wes Anderson

\section{Zakaj je pomembno biti »na poti«: Branje popotovanja v Darjeeling Limited (2007) Wesa Andersona}

\section{POVZETEK}

Zgodbe ceste so pomembni kulturni objekti, ki »nudijo pripraven prostor za raziskovanje« (Cohan and Hark 1997, 2) raznolikih krajin in tako prispevajo k srečevanju potujočega s samim seboj ali z Drugim. Takšna kulturna srečevanja so priložnost za notranjo refleksijo o narodih, v katerih se protagonisti gibajo. Tak je tudi primer bratov Whitman v The Darjeeling Limited (2007, Wes Anderson), ki se odpravijo na popotovanje po Indiji, med katerim iščejo duhovno razsvetljenje in se soočajo s svojo preteklostjo. Spopad s tujim Drugim jim na novo osmisli tako predstave o Indijcih kot življenjske cilje. Članek z vidika transformacijske moči popotovanj in prek analize filma The Darjeeling Limited kot filma ceste proučuje prebujenje bratov, ki na poti do samospoznanja potujejo vse globlje v indijsko krajino.

Ključne besede: popotovanje; zgodbe ceste; kinematografija; transformacija; The Darjeeling Limited; Wes Anderson. 


\title{
The Importance of Being 'On the Road': A Reading of the Journey in The Darjeeling Limited (2007) by Wes Anderson ${ }^{1}$
}

\author{
"There are no foreign lands. It is the traveller only who is foreign."- Robert Louis Stevenson
}

"In a world in which there's no more 'away' and in which distance has disappeared, do road movies still have a reason to exist?" - Walter Salles

\section{Introduction}

In an article entitled "From Easy Rider to Nebraska: The road movie allure," Jordan Hoffman (2013) explains that the road movie has been one of the most enduring genres in the history of Hollywood, especially because it has been used as a "ready space for [the] exploration" (Cohan and Hark 1997, 2) of different cultural landscapes. In fact, the genre continues to be valued as an important tool to chronicle the major changes that have occurred throughout time, as it generates new perceptions upon the questions of identity and belonging, possibility and transformation. By focusing on the importance of movement and displacement, the road movie provides a unique opportunity to look at many aspects of the American nation, since it registers the experiences and feelings expressed by the travellers in their search for meaning.

The 20th and 21st centuries saw an explosion of road stories throughout the world, giving voice to the many challenges of contemporary society, thus presenting alternative visions to the ones already established. Filmmakers are constantly returning to the road movie genre because its potential lies within its flexibility to accommodate multiple worldviews, as Hoffman (2013) comments:

[The road movie] is also enormously flexible: it can take in other genres, comment on political issues or set out a philosophical worldview. This is one reason the road movie has remained consistently popular since the advent of sound cinema - with detours and potholes here and there.

The openness to adapt to the different circumstances and, indeed, to respond to certain key moments in history is what makes the road movie such an appealing genre to spectators and filmmakers alike. The genre became so popular that it was imported from the United States ${ }^{2}$ to other nations as a cultural vehicle in which directors could explore the crises and the tensions of their own country or of another foreign country. In this sense, the road movie genre stands as an important visual document that registers and accommodates different identities and cultural maps that emerge in contemporary society (Mills 2006, 18).

This article is based on the author's PhD thesis (Duarte 2014), University of Lisbon.

It is important to note that there are some critics who argue that the road movie is not solely a genre born in the United States, in the sense that other journeys on the road can likewise be traceable in other nations, more or less at the same time as Bonnie and Clyde (1967, Arthur Penn) and Easy Rider (1969, Dennis Hopper), the founding narratives of the road movie. However, in line with Corrigan (1991) or Laderman (2002), these films will be considered the roots of the road movie in this essay as well. 
Adding to the innumerable film productions - both American and foreign - it is important to note the rise in critical thought on road movies, particularly in what concerns non-American productions, like in Brazil, France or in South America in general. ${ }^{3}$ These studies contribute to highlighting the importance of this genre worldwide and are a good example of the global impact of road pictures. However, the purpose of this study is not to explore these particular works.

Instead, attention will be given to the road movie genre in the United States, followed by an analysis of The Darjeeling Limited (2007), understood here as a renewed version of the classical notion of a road story. Wes Anderson's film is a good example of how mobility continues to play an important role in constructing one's identity. By travelling to and within the Indian landscape the main protagonists of the film - the Whitman brothers - will be able to flow in between loss and discovery and slowly renew not only their trust in each other as family, but also as individuals.

What makes The Darjeeling Limited such an interesting case study is the fact that the filmmaker chose a foreign nation - India - to explore the doubts and uncertainties of the main characters. This is particularly relevant considering how the road story inquires into transformation occurring outside familiar territory. By travelling in an alien culture the brothers are confronted with their own self as new perspectives are revealed, making them embrace the difference embodied by the (Indian) Other but at the same time by themselves.

With this in mind, and for the sake of better organization, this article is divided into three major parts. The first section encompasses an introduction to the road movie, by trying to provide a brief history of the genre and its major characteristics, with special attention given to contemporary works. A theoretical framework related with the road movie and its impact supports this short introduction to the genre.

The second part will analyze The Darjeeling Limited (2007), taking into consideration the protagonists' journey to India and their confrontation with the Other, and how this opposition helps the Whitman brothers rediscover themselves. In this sense, what is to be proven here is why journeys matter and, in particular, why road movies continue to play such a significant part in our cinematic culture. This latter issue will be explored in the concluding remarks titled "Why do journeys matter?"

\section{The Road Movie: Some Notes}

According to Hayward (2006, 335), "[r] oad movies, as the term makes clear, are movies in which the protagonists are on the move." This brief definition is further developed by Hayward in her book, in which she points out other features that contribute to better defining the genre. Historically speaking, the relation between 'man + car + road' could already be noticed in many books and films before the $1960 \mathrm{~s},{ }^{4}$ as the road movie is "very much a postwar phenomenon" (Corrigan 1991, 143), in which technology, in particular all kinds of motorized vehicles, ${ }^{5}$ played an important role. Cars, trucks or motorcycles, for instance, are present in the majority of road movies, promoting the possibility of escaping the system and providing a new beginning.

See, for instance, the studies of Archer (2012), Brandellero (2013), and Pinazza (2014).

Jack Kerouac's On the Road, published in 1957, is one of the major literary influences of the road movie. Some films produced before Easy Rider, like It Happened One Night (1934), by Frank Capra, also had a major impact.

5 The road movie succeeds another well-known American genre, the Western, by continuing to explore - now in a modernized version due to technology - the significance of the American landscape, the importance of the quest and the imagination of the "nation's culture" (Cohan and Hark 1997, 3). 
While on the road, most protagonists end up learning valuable lessons that will play a part in their better understanding of themselves and the world. In a sense, the road film protagonist is travelling into the unknown, on a journey from one place to another that will help them rediscover the landscape.

An interesting definition for road movies is the one presented by Correa in an article where he tries to pinpoint the main features of the genre. For him, the road movie is characterized by the presence of travelling heroes or nomad characters - mainly young, male, marginal figures - wandering around the country in search of themselves $(2006,272)$.

Easy Rider, the film directed by Dennis Hopper in 1969, is a good example of Correa's definition of the genre. Considered by many critics and film historians the first road movie, along with Bonnie and Clyde (1967, Arthur Penn), it specifically focuses on Wyatt and Billy's journey across the nation in search of the real America, hence possessing many of the features that characterize the genre.

Both films were produced at a time of rebellious impulses towards the ruling system. As Laderman suggests $(2002,43)$, these narratives are "propelled in spirit and theme by the visionary rebellion of the counterculture." While Bonnie and Clyde is a narrative celebrating the couple's "fugitive mobility" (Laderman 2002, 43), Easy Rider celebrates the possibilities offered by the open road and, at the same time, relates to the countercultural critique typical of the 1960s. This division seems to lead to two different paths: (1) the outlaw road movie descending from Bonnie and Clyde, and (2) the quest road movie, descending from Easy Rider. The division presented here is not always well-defined, since on many occasions the road movie narrative possesses elements from both types.

Easy Rider's narrative praises the importance of mobility in pursuit of the true America, but it is also proof that it is possible to be disenchanted while on the road, since in the end, their search for the true America fails. This is especially true in the final scene, where both Wyatt and Billy are confronted with a cultural Other - represented by the 'redneck' group, and here understood as an oppressive group that is against what is 'different' - who is unable to accept them and what they stand for and, therefore, eliminates them from the road and, of course, from the nation's landscape. In this sense, the quest for the true American nation is unsuccessful when opposed by the forces of conservatism that do not tolerate alternative views and ways of life. Wyatt and Billy's position can only be marginal and nothing else.

Hopper's film is a good example of some of the existing tensions in road movies, paving the way for future road stories. The ending in Easy Rider, for instance, would be very important in the following decade, since the 1970s narrative focuses its attention on doubting the promise of the open road, as Laderman notes $(2002,81)$ : "Still modernist, the road movie's proliferation during this period is characterized by a movement away from the idea(l) of social rebellion, toward exaggerated cynicism, irony and nihilism." Films such as Two-Lane Blacktop (1971, Monte Hellman) or Vanishing Point (1971, Richard C. Sarafian) are two good examples of how the road can often lead to nowhere and be devoid of sense. In these films, driving is just an act in itself because the excitement of being on the road is transformed into emptiness.

The 1980s recover the rebellious feature of the road story thriving in the postmodern era, in particular within the sphere of independent cinema. Paris, Texas (1984, Wim Wenders) or Stranger than Paradise (1984, Jim Jarmusch), for instance, illustrate how the postmodern road 
movie continues with the rebellious features of the 1960s, only to become self-conscious about it, pervading the road movie with irony and exaggeration. The road movie flourishes in the 1980s and, in the 1990s, brings new ways of looking at the journey, renewing some of the themes explored in previous decades (identity problems, cultural tensions, or the dissolution of the family, to name a few). A closer look at some of the road stories produced during this decade testifies to the openness of the road movie to multicultural issues that are not present in the white-male-only narratives of the previous decades.

Thelma and Louise (1991, Riddley Scott), My Own Private Idaho (1992, Gus Van Sant), Get on the Bus (1996, Spike Lee), Smoke Signals (1996, Chris Eyre) or The Straight Story (1999, David Lynch) invert some of the codes of the road movie and reuse its counterculture discourse to express the issues of their own specific communities. As Mills points out $(2006,188)$ in her reflection on the road movie, the 1990s reveal the importance of the transformation while on the road:

The road remains a space of metamorphosis, as it has been throughout the postwar decades, but in the nineties this evolution extended beyond those who travel on the road to those communities touched by the protagonist who travels. Alienation exists only as a conflict to be resolved through the community's transformation rather than the individual's rebellion. Walt Whitman once noted, "I am bigger than I thought myself," and the films of the nineties shift focus from the self to the interconnections of that self to a larger group of people.

Not only do the nineties renovate the genre, they also revitalize it by giving voice to important groups of the nation that up until then were on the margins. Taking a look at each of the films individually, Thelma and Louise puts, for the first time, two women on the road, while My Own Private Idaho revolves around two gay characters, and Smoke Signals as well as Get on the Bus put into perspective the Native-American and African-American communities, centering their attention on the social tensions of the time by exploring questions of identity and belonging, thus presenting to viewers an unfamiliar and marginalized cultural landscape previously unknown to them. Finally, The Straight Story challenges the genre itself by placing an elderly man on the road. The main character, Alvin Straight, goes against the road movie convention of young fast-driving males on the road by driving a slow-moving lawnmower. All in all, with the 1990s road movies, it becomes clear that the genre travels in many different directions, particularly because it becomes difficult to just talk about 'road movies'.

Describing the road movie genre in the 21 st century is a very complex task, as the term has become difficult to define in recent years; it encompasses many different features, especially with genre blending. The road movie narrative is no longer just connected with journeys in the traditional sense. In other words, the journey is not only made by car, it can also include travelling by foot, hence expanding the road movie's potential and focusing on a voyage that is much slower and, in a sense, more introspective, like in the case of Into the Wild (2007, Sean Penn) or Wendy and Lucy (2008, Kelly Reichardt).

The amount of road stories produced in the last decade continues to rise, possibly because the genre explores a variety of different issues, and responds to the crises and tensions of each decade, as demonstrated in these brief notes. In the case of contemporary road movies, for instance, the characters seem to travel through an identity crisis, angst and the inability to be responsible and grow up, addressing the genre's "potential for romanticizing alienation" (Cohan and Hark 1997, 1). Some of these issues can especially be observed in contemporary narratives like Garden State (2004, Zach Braff) - a clear example of the road movie's flexibility - or Sideways (2004, Alexander Payne). 
Now that some of the recurrent motifs of the road movie have been established, let us move on to the second part of this article, an analysis of a contemporary road story like The Darjeeling Limited that puts the main protagonists on a journey in a non-American landscape towards self-discovery and emotional fulfillment.

\section{Contemporary Journeys: A Reading of the Journey in The Darjeeling Limited (2007) by Wes Anderson}

Before embarking on the film analysis per se, it is important to state that Wes Anderson is not a typical director and that The Darjeeling Limited, like most contemporary road stories, is not a classic road movie. Anderson is a very peculiar filmmaker, in the sense that he is involved in the whole process of film creation, as Browning (2011, ix) expresses:

Anderson is a rare example of a modern director who has a significant input in a number of areas of production, resulting in a distinctive style, which links his films together and separates them from the work of others. He directs, writes, and sometimes produces, and takes an almost forensic approach to the look of his sets.

The complete immersion in all the aspects of his films gives him a certain freedom to make real his vision as an auteur. The Darjeeling Limited is a curious case in Anderson's filmography, since it is set in India ${ }^{6}$ and, therefore, estranged in a certain way from his other films. However, some of the issues portrayed in this film do not stray from the ones explored in his previous creations; special attention is placed on the themes of family dissolution and confrontation, parenthood, and a certain alienation and apathy towards reality. Another recurrent theme is the journey, and the possibility it presents even if the type of emotional transformation at the end of the film is not conclusive, like in the case of The Life Aquatic with Steve Zissou (2004).

The Darjeeling Limited is set on a train and not on a road, as the train is one of the most important means of locomotion in India. Notwithstanding, and taking into consideration my previous reflection upon contemporary road stories, the film can be understood as "an update of the classic American road movie" (May 2009) as the brothers - much like in Easy Rider - are in search of a deep transformation that will occur at the end of their journey. The Darjeeling Limited addresses the journey of three brothers (the Whitman brothers), Francis (Owen Wilson), Peter (Adrien Brody) and Jack (Jason Schwartzman), who, a year after their father's death, go to India in search of their mother. Contrary to most road movie conventions, the Whitman ${ }^{7}$ brothers travel not by car, but by train, which is quite significant.

If the isolation of the $\operatorname{car}^{8}$ encourages the confrontation between travelers, the journey by train is especially peculiar, as it denotes a return to the past and (although parts of the journey are done by other means of transport) represents a change in the characters' emotional state: they are not the same as when they depart and, indeed, they do not enter the same train at the end of the film, a metaphor for their change. The Darjeeling Limited is a road story in a broader sense of the term, since it combines almost all the tropes previously presented: movement, confrontation, inner

$6 \quad$ It is important to note that the viewer assumes the country depicted in the The Darjeeling Limited is India, but it is never mentioned that the film's country is in fact India.

Also noteworthy is that the name Whitman is a clear reference to the American poet Walt Whitman, who wrote "Song of the Open Road," published in Leaves of Grass (1856), where he celebrates the importance of the road in American culture, as the place for learning about one's own being.

8 The train carriage plays a similar role to that of the car, as it represents an isolated place where the tensions and crisis between the brothers take place and can also be resolved. 
reflection and, finally, a possible change. The Whitman brothers, as in most buddy films, ${ }^{9}$ need to solve their problems while on the road - which is here represented by train tracks - and, at the end, understand their inner self so as to embark on a new life.

In addition to identifying the importance of the journey, the aim here is to look at the way the Indian landscape plays a significant role in the transformation of the three brothers, since the journey throughout India will accommodate the characters' coming to terms with their problems and losses. In order to better understand the emotional catharsis of the brothers, the film will be examined from two different perspectives. Firstly, it is necessary to understand how Francis, Peter and Jack fail to perceive the cultural landscape in which they are inserted. At the beginning of the film - and indeed throughout the greater part of the narrative - the brothers opt to play the role of the Western tourist who favors a mystical version of India rather than the real nation. ${ }^{10}$ For the Whitmans the simple act of being in a foreign nation is enough for spiritual illumination and emotional change, but they seem oblivious to the reality that surrounds them.

Only after being adrift and without a guide ${ }^{11}$ do they slowly abandon their Western view in favor of a more non-Western perspective. Nonetheless, though they do not truly grasp the real meaning of the foreign country through which they are travelling, they seem to get a glimpse of the real India, a place that will be important in the transformative experience of the brothers, as they slowly solve their problems. It is with this in mind that the second part of the film analysis will consider and reflect on how this transformation occurs.

In The Darjeeling Limited each character carries some sort of emotional baggage: Francis tried to kill himself, Jack suffers due to the breakup with his girlfriend ${ }^{12}$ and Peter cannot overcome the death of their father, as well as accept his responsibility as a soon-to-be parent. At the same time, the brothers have a difficult relationship with each other: Peter only talks to Jack about his problems and vice-versa, and Francis seems obsessed with being in control of his brothers. He is also the one responsible for the organization of the journey to India, possibly in search of a spiritual awakening that will reinforce the bond between them.

Regardless of Francis' attempt, the intent on experiencing India as a spiritual place becomes a complete farce due to how the brothers undermine that very notion, travelling like tourists - in a carriage that only a privileged few can afford ${ }^{13}$ - and by not making an effort to experience and respect the country through which they travel. Indeed, in a study on the masculine crisis in Wes Anderson films, Robé $(2013,120)$ expresses a view where he considers The Darjeeling Limited a racist film where "Eurocentric pain and desires constantly trump that of the Indian characters." Francis, for instance, always wanting to be in control, maps out a complete itinerary

9 The buddy film is a cinematic subgenre that can be usually included within the context of the road movie. While most road movies focus on a one-man journey, the buddy film usually portrays two friends in conflict on the road and it is only on the road that their conflicts can be overcome. A good example of a road movie/buddy film is Sideways (2004, Alexander Payne). Similarly, The Darjeeling Limited is in line with the buddy film; however, instead of two friends, Anderson choses three brothers. For a more detailed description of the buddy film, see the relevant chapter in Casper (2011, 247-52).

10 According to Bill Ashcroft et al. (1998, 97), contemporary tourism can be understood as an updated version of the exploratory travels of the 19th century where "[t] he tourist enters the territory of the Other in search of an exotic experience." This seems to be case of the opening scenes of The Darjeeling Limited, but the film is much more than that, since it is my belief that the brothers do achieve a transformation due to a better understanding and respect towards India.

11 At a certain point in the film, Francis ends up dismissing the guide, his personal assistant.

12 This story is told in Hotel Chevalier (2007), a short film that was exhibited along with The Darjeeling Limited and that can be seen as a kind of prologue to the feature film.

13 More than that, as Bose $(2008,3)$ suggests, the exaggerated colors of the carriage, as well as of other elements, seem to be an ironic play by Anderson on the way Westerners imagine India. 
for their journey, not leaving any room to really appreciate and take in the landscape. In addition, as Browning proposes $(2011,80)$, Francis' notion of a spiritual journey is one that includes his own daily routine, which implies, in a certain way, his own emptiness and self-centered views of the world. This lack of depth can likewise be seen in the way Jack seduces Rita, the Indian waitress, or in all the Louis Vuitton suitcases and objects the brothers carry with them: Francis' leather belt and loafers (a symbol of consumerism), pain killers, perfume, car keys, including a poisonous snake that Peter buys and that will eventually be responsible for their expulsion from the train.

In this sense, the brothers become the Other, since they become the object of profound irony when in contrast with the Indian landscape. I am considering here the Other as defined by Ashcroft et al. $(1998,169)$ : “The colonized subject is characterized as 'other' [...] as a means of establishing the binary separation of the colonizer and colonized and asserting the naturalness and primacy of the colonizing culture and world view." The Other, as Ashcroft et al. develop, becomes the way in which difference and identity is established, in a sense "the norm against which everything is measured" (Nadel 1997, 184). In The Darjeeling Limited the first impression we get of the brothers is that their look upon India obeys the stereotypical notions portrayed by Western culture towards the East. However, this opposition seems more a critique of the Western world, as the brothers dedicate themselves to futile actions while at the same time expecting to have a moment of great revelation.

Instead of searching for true meaning in their journey, they prefer to dedicate themselves to consumerism and to touristy activities. These activities become the object of mockery, for instance, in the scene where the children looking down from the rooftops start laughing at their awkward appearance, as Nandana Bose $(2008,3)$ explains:

A key sequence depicts Indian children on roof-tops, diegetic spectators who assume the position of the non-Western viewer, laughing at the obvious awkwardness and discomfiture of the three brothers who are clearly marked as foreign/Other, attired in their crisp suits that are incongruous in the heat of Rajasthan, heavy garlands hanging like nooses around their necks and sporting red tikkas (dots) on their foreheads.

In her study on the film Bose considers The Darjeeling Limited a reflective critique on Orientalism, ${ }^{14}$ where the discourse suggesting the exotic (Other) as inferior, mystical or sexual is ironic. It is significant to point out that, as Nadel notes $(1997,184)$, for American audiences the discourse and representation of the exotic Other is a reproduction of the English modes of representation in the 19th century. The author gives an example of Gunga Din (1939, George Stevens), which is based upon the poem of the same name by Rudyard Kipling and is a film saturated with stereotypical images of India: exotic, inferior, but also highly dangerous. ${ }^{15}$ As already mentioned, the first scenes from The Darjeeling Limited do correspond to an oversimplified vision of the India landscape, with the brothers embodying an orientalist vision that is being parodied by Anderson.

14 For a better understanding of this question, see Bose's 2008 paper, which is based upon a reading of the film supported by Edward Said's influential 1970s work Orientalism. I am considering here Orientalism as defined by Ashcroft et al. (1998, 168): "The significance of Orientalism is that as a mode of knowing the other it was a supreme example of the construction of the other, a form of authority. The Orient is not an inert fact of nature, but a phenomenon constructed by generations of intellectuals, artists, commentators, writers, politicians, and, more importantly, constructed by the naturalizing of a wide range of Orientalist assumptions and stereotypes. The relationship between the Occident and the Orient is a relationship of power, of domination, of varying degrees of a complex hegemony."

15 Although Wes Anderson is influenced by George Stevens' film, in The Darjeeling Limited he produces an ironic ironic vision of the Whitmans' futile and stereotypical comments. 
Yet, as the film progresses the brothers seem to be affected by India, particularly after a scene that puts everything into a different perspective; it is the river sequence, ${ }^{16}$ in which the family's disagreements are put aside in order to save three other brothers who are drowning. Francis and Jack manage to save two children, but Peter fails to do so - "I didn't save mine." The following scenes present the Whitman brothers in a small Indian village in which they are invited to spend some time after the river incident. In this particular scene, the spectator gets a glimpse of the true connection established between the brothers and the Other foreign culture; for instance, Jack helps with flowers, Francis with some of the children of the village and Peter, the soon-to-be father, holds a baby on his lap.

The moment becomes even more intense when the brothers are asked to attend the funeral of the child Peter was unable to save. The images of the funeral held in the village are superimposed with a flashback from Jimmy Whitman's funeral (the Whitman brothers' father) to reveal the contrast between traditions and rituals. While in the first case the villagers are dressed in white, in the latter the brothers are dressed in black. Furthermore, for the villagers, death seems to be a natural part of life and, therefore, there is a different understanding of the grieving process and of the pain in losing someone dear.

All the same, this experience creates an opportunity for the brothers to bond and realize the importance of family. As the brothers wash themselves in the nearby river - a metaphor for purification - the viewer senses some spiritual growth and, in fact, upon reaching the airport, each character seems to seek redemption. Francis not only apologizes to his assistant and asks him to go back to work for him, but he also acknowledges the need to continue his healing process, both physical and spiritual; Jack calls his ex-girlfriend; and Peter calls his wife to tell her he is ready to assume his parental duties.

The journey would not be complete without the brothers encountering their mother. Their reunion, when exiting the airport, corresponds to a new understanding of the family dynamics. By confronting Patricia Whitman, they are finally able to bury the past and move on with a fresh perspective in what concerns the present and the future, symbolized in the ritual they perform with the feathers. ${ }^{17}$ Now, more than ever, the Whitman family is ready to embark on a new journey.

Contrary to what Browning claims $(2011,87)$, I would argue that India performs an important role, a "choric function, a primordial, timeless presence" (Bose 2008, 6), a backdrop where the brothers can learn to once again trust each other. Moreover, the fact that they represent both the Other and are confronted with the Other is a fundamental element in their transformation, since it allows them to look at the landscape from a different perspective. Being away from their comfort zone and from their busy lives and routines gives the brothers the opportunity to slow down and access a deeper meaning of life.

At the end of the film, the brothers manage to catch another train to return home, one that symbolizes their transformation. Special attention must also be given to Peter, who no longer feels the need to wear his father's sunglasses, a sign that he has overcome his grieving period. Furthermore, in order to catch the train, they all discard their expensive suitcases, an action that functions as a double metaphor. Firstly, it stands for how they are emotionally lighter and, secondly, the brothers

16 A reference to the film The River (1951, Jean Renoir), also set in India, in which Renoir tried to avoid the British Imperialist vision and where "he rejected the India of exotic action and spectacle" (Christie 2005).

17 Although the ritual is somehow the object of mockery, this is an interesting turning point in the Whitmans' journey; they are finally ready to continue with their life as adults and are able to understand their inner emotional conflicts. 
have finally reached a higher spiritual stage by getting rid of their symbols of materialism. It is true that Anderson does not try to encounter a mystical purpose in life as he explores India, because although the brothers have in fact changed, there are still many issues to be resolved.

Nonetheless, as Penner $(2011,73)$ mentions, the brothers are at least transformed in two ways: (1) they no longer see themselves in the same way both individually and as a family; (2) the brothers have learnt to appreciate India differently, now "as an equal rather than a subordinate nation." After all, the Whitman brothers - as their name indicates - are now ready to be "pioneers of the open road" (Duarte 2014, 223), that is, ready to discover what this new journey holds in store for them.

\section{Conclusion: Why Do Journeys Matter?}

This essay has been an analysis of the importance of road stories and their meaning. My aim was to look at the history of road movies and the way each decade remaps how journeys are depicted. As Mills $(2006,223)$ observes, by focusing on powerful themes, such as identity and change, the road movie is constantly faced with new challenges.

Taking into consideration a film like The Darjeeling Limited, the aim here was to examine how Anderson explores the concept of identity crisis in a specific foreign nation, in this case, India. By considering the film a renewed vision upon the road story, this study inquired on the importance of the Whitmans' need of spiritual and emotional growth.

As illustrated throughout the film, although this is an atypical road movie, The Darjeeling Limited displays almost all the distinctive traits of the genre. The Whitmans' journey is purposefully slow, decisively going against today's rapidly changing world. This is an especially recurring feature of most recent road movies, which no longer seek the thrill of motion and speed or of the open road, but rather immerse themselves in deep contemplation and inner reflection.

This is an understandable reaction, since road movies, according to the Brazilian director Walter Salles (2007), challenge the culture of conformity. They are a form of resistance in today's complex global village, claiming independence over the system and ultimately reclaiming one's own identity in the end, as Mills $(2006,233)$ comments:

Optimism, subversion, opportunity and innovation - these are the recurring themes of the road genre, and they should be ours as well. Over the past sixty years, the road story has served as a kind of declaration of independence, offering a vision of how we might break free of unwanted loyalties and obligations to create new identities for ourselves.

The response to the question posed, why journeys matter, is that they matter because they offer everyone the possibility of claiming their own identity, providing the opportunity to learn about themselves and about the Other. Journeys matter because we continue to believe in possibilities and transformation. The road movie has been exemplary in this sense, surviving throughout decades, renovating itself (Mills 2006, 223) to tell the right stories and voice the predicaments of our time.

The Whitmans' travel within India is, in fact, an expression of the tensions and crisis of a certain American white middle class that cannot find its place and lives in a perpetual malaise and existential uncertainty. The protagonists' lack of emotional depth and understanding is revealed in the superficial comments on the foreign nation, one that they can only perceive through the lenses of the capitalist Westerner. They are constantly obsessed with buying exotic objects, such as the snake, or with finding an immediate response to their problems by simply praying in religious 
spaces. This primary, romantic notion only heightens the senseless purpose of their spiritual quest and, at the same time, of the modern way of living, one that prevents the full experience created by this journey.

In spite of that, as the brothers go deeper into the foreign landscape - and are lost and found - they seem to grasp the real meaning of the journey. From one train to another, in between tracks, the brothers learn the value and importance of family and of understanding each other, particularly after the funeral scene, a moment that contrasts with Jimmy Whitman's funeral (fast paced, confusing and cynical), with little space for true mourning. If there is a critique implicit in The Darjeeling Limited, it is the emptiness that characterizes contemporary American society.

Anderson's choice to insert the narrative in a foreign nation is to go back to a moment that recovers the importance of a constant renewal of the collective and individual self. The result is that the brothers restore their trust in each other. This can only be achieved by a distancing from their original culture and, as the journey progresses, the Whitmans free themselves from their heavy past: they get rid of small objects but also of the heavy baggage, an obvious metaphor for a spiritual uplifting.

If for some The Darjeeling Limited is, as Weiner (2007) claims, "[Anderson's] most obnoxious movie yet," for others (Bose 2008; Duarte 2014) this particular narrative is representative of the Andersonian cinematic universe, characterized by a certain ironic look upon the white American middle class: constantly on the lookout for emotional fulfillment. It is also true that the ending scene is not very conclusive. Although we sense some sort of transformation, the Whitmans still have a long way ahead, proof that in most contemporary road stories the road - or, for that matter, the tracks - functions as the place for a continuous spiritual reflection.

What also seems to be implicit in The Darjeeling Limited is that the American landscape is no longer sufficient for spiritual contemplation due to its fast-moving way of living. By inserting this story outside the brothers' reality, Anderson is forcing them to embark on a journey that will highlight the importance of brotherhood, family and that, above all, is a way of expressing true feelings. In Anderson's world the brothers are seen as marginal or outside figures who can no longer relate to their own country and have become unable to experience true emotion. Lost without a father and abandoned by their own mother, the Whitmans represent a nation immersed in ennui, oblivious to the necessity of introspection towards spiritual awakening, devoid of purpose and direction.

In this context, the Indian landscape, more than being the object of an orientalist vision, is the place of new beginnings, arrivals and departures, gradually opening itself to the renewed interpretation of the brothers now that they are also willing to accept a new path, no longer blurred by their own past or selfish way of living, but characterized by a new fierceness - the tiger no longer a menace - towards life and the living.

\section{References}

Archer, Neil. 2012. The French Road Movie: Space, Mobility, Identity. Oxford: Berghahn.

Ashcroft, Bill, Gareth Griffiths, and Helen Tiffin. 1998. Key Concepts in Post-Colonial Studies. London: Routledge.

Bose, Nandana. 2008. "The Darjeeling Limited: Critiquing Orientalism on the Train to Nowhere." Mediascape: UCLA's Journal of Cinema and Media Studies, Spring '08:1-8. Accessed November 24, 2014. http://www.tft. ucla.edu/mediascape/spring08 darjeelinglimited.pdf. 
Brandellero, Sara, ed. 2013. The Brazilian Road Movie: Journeys of (Self) Discovery. Cardiff: Wales University Press.

Browning, Mark. 2011. Wes Anderson: Why His Movies Matter? Santa Barbara: Praeger.

Casper, Drew. 2011. Hollywood Film 1963-1976: Years of Revolution and Reaction. West Sussex: Wiley-Blackwell.

Christie, Ian. 2005. "The River." The Criterion Collection, February 28. Accessed March 29, 2015. http://www. criterion.com/current/posts/357-the-river.

Cohan, Steven, and Ina Rae Hark. 1997. "Introduction.” In The Road Movie Book, edited by Steven Cohan and Ina Rae Hark, 1-14. London: Routledge.

Correa, Jaime. 2006. "El Road Movie: Elementos para la Definición de un Género Cinematográfico." Cuaderno: Música, Artes Visuales y Artes Escénicas. 2 (2): 270-301. Accessed November 23, 2014. http://revistas. javeriana.edu.co/index.php/cma/article/viewFile/6437/5118.

Corrigan, Timothy. 1991. A Cinema without Walls: Movies and Culture after Vietnam. New Brunswick: Rutgers University Press.

Duarte, José. 2014. "Like Branches in a River: Viagens Estrada afora e Cidade adentro no Cinema Americano." $\mathrm{PhD}$ diss., University of Lisbon.

Hayward, Susan. 2006. Cinema Studies: The Key Concepts, 3rd ed. Abingdon: Routledge.

Hoffman, Jordan. 2013. "From Easy Rider to Nebraska: The Road Movie Allure.” BBC Culture, December 10. Accessed January 16, 2015. http://www.bbc.com/culture/story/20131210-road-movies-never-out-of-gas.

Laderman, David. 2002. Driving Visions: Exploring the Road Movie. Austin: University of Texas Press.

May, Emily J. 2009. "The Darjeeling Limited and the New American Traveller." Senses of Cinema 49. Accessed March 19, 2015. http://sensesofcinema.com/2009/feature-articles/darjeeling-limited/.

Mills, Katie. 2006. The Road Story and the Rebel: Moving through Film, Fiction, and Television. Illinois: Southern Illinois University Press.

Nadel, Alan. 1997. "A Whole (New) Disney World Order: Aladdin, Atomic Power and the Muslim Middle East." In Visions of the Eats: Orientalism in Film, edited by Matthew Bernstein and Gaylyn Studlar, 184-203. New Brunswick: Rutgers University Press.

Penner, Timothy. 2011. “The Allusive Auteur: Wes Anderson and His Influences.” MA Diss., University of Manitoba.

Pinazza, Natália. 2014. Journeys in Argentine and Brazilian Cinema: Road Films in a Global Era. New York: Palgrave Macmillan.

Robé, Chris. 2013. “'Because I Hate Fathers, and Never Wanted to be One’: Wes Anderson, Entitled Masculinity, and the 'Crisis' of the Patriarch." In Millennial Masculinity: Men in Contemporary American Cinema, edited by Timothy Shary, 101-21. Detroit: Wayne State University Press.

Salles, Walter. 2007. "Notes for a Theory of the Road Movie." New York Times, November 11. Accessed December 12, 2014. http://www.nytimes.com/2007/11/11/magazine/11 roadtrip-t.html.

Weiner, Jonah. 2007. “Unbearable Whiteness." Slate, September 27. Accessed December 12, 2014. http://www. slate.com/articles/arts/culturebox/2007/09/unbearable whiteness.html.

\section{Filmography}

Bonnie and Clyde. 1967. Directed by Arthur Penn. Warner Brothers/Seven Arts.

Easy Rider. 1969. Directed by Dennis Hopper. Columbia Pictures Corporation. 
Garden State. 2004. Directed by Zach Braff. Camelot Pictures, Jersey Films.

Get on the Bus. 1996. Directed by Spike Lee. Columbia Pictures, 40 Acres \& A Mule Productions.

Gunga Din. 1939. Directed by George Stevens. RKO Radio Pictures.

Hotel Chevalier. 2004. Directed by Wes Anderson. Fox Searchlight Pictures.

Into the Wild. 2007. Directed by Sean Penn. Paramount Vintage.

It Happened One Night. 1934. Directed by Frank Capra. Columbia Pictures Corporation.

My Own Private Idaho. 1991. Directed by Gus Van Sant. New Line Cinema.

Paris, Texas. 1984. Directed by Wim Wenders. Road Movies Filmproduktion.

Sideways. 2004. Directed by Alexander Payne. Fox Searchlight Pictures.

Smoke Signals. 1996. Directed by Chris Eyre. ShadowCatcher Entertainment.

Stranger than Paradise. 1984. Directed by Jim Jarmusch. Cinesthesia Productions.

The Darjeeling Limited. 2007. Directed by Wes Anderson. Fox Searchlight Pictures.

The Life Aquatic with Steve Zissou. 2004. Directed by Wes Anderson. Fox Searchlight Pictures.

The River. 1951. Directed by Jean Renoir. Oriental International Films.

The Straight Story. 1999. Directed by David Lynch. Asymmetrical Productions.

Thelma and Louise. 1991. Directed by Riddley Scott.

Two-lane Blacktop. 1971. Directed by Monte Hellman. Michael Laughlin Enterprises, Universal Pictures.

Vanishing Point. 1971. Directed by Richard C. Sarafian. Cupid Productions, Twentieth Century Fox Film Corporation.

Wendy and Lucy. 2008. Directed by Kelly Reichardt. Field Guide Films, Film Science. 